\title{
The Currency of the Russian Empire in the Culture of the Yugra Indigenous Peoples: Practical Aspects of Colonialism and Reflections on Multiculturalism*
}

\section{Olga N. Naumenko}

Yugra State University, Khanty-Mansiysk

\section{Julia A. Bortnikova}

International Institute of Innovative Education, Tyumen

\section{Egor E. Naumenko}

Tyumen State University

\begin{abstract}
The present article considers the history of introduction of monetary circulation into the life of the Ob-Ugrian peoples, namely, of the Khanty and Mansi people residing in the territory of Yugra area, in comparative context with the descending from them Siberian Tatars. The authors contest the accepted idea of necessary maintenance of culture of the aboriginal peoples of the North in the initial state since their culture turns to be unable of adapting to changing economic and cultural and historical context which leads to the nation's dying out. By the example of the Siberian Tatars, the authors substantiate a new form of multiculturalism resulting from the interfusion of cultures which turns a favourable factor for adaptation of an autochthonous nation to the state economic policy.
\end{abstract}

\section{INTRODUCTION}

Historically, Yugra was one of the most significant regions in the Russian empire since its natural resources served a means for treasury replenishment. Therefore, any financial and economic reforms there, especially among the Ob-Ugrians and Tatars as well as fur trappers, 
who paid non-monetary rent, were of strategic value. Throughout the Russian empire history a gradual replacing of fur skins as an exchange equivalent to Russian money took place. At each stage this process involved ambiguous, at times contradictive policy decisions which finally led to the destruction of the Khanty and Mansi traditional economic order; however, it also encouraged involving the Siberian Tatars into the state economic life. Such a negative result of the national policy was caused by a number of reasons; and the key factor was the peculiar position of these peoples in the Western Siberian cultural and historical environment.

The source database of our research includes legal acts, business documentation, ethnographical evidence, and collections of coins. We also apply the civilizational methodological approach which helps clarify the conflict between cultures resulting from the implementation of monetary policy and allows making forecasts with respect to their further mutual coexistence. The authors apply the updating method and also retrospective and comparative historical approaches. The updating method allows revealing the elements of the Ob-Ugrian culture that are mostly exposed for destruction. The retrospective approach enables to study the problem through the lens of the world view of people of the eighteenth - early twentieth centuries, their knowledge and experience. The comparative historical approach provides an opportunity to trace the implementation of reforms at particular stages, as well as in the comparative context with the Siberian Tatars: historians infrequently apply this methodological approach when studying two cultures (Lempert 2014: 99-134).

Our objective is to reconsider the Russian empire policy concerning the currency circulation among the Ob-Ugrians (mainly residing in the northern part of Yugra and confessing shamanism) in comparison with the Siberian Tatars, who densely inhabit the southern parts of the region and confess Islam. The Ob-Ugrian ethnic group includes the Khanty (Ostyaks) and the Mansi (Voguls) peoples. The indigenous peoples of Yugra involve the groups following traditional cultural principles in their lives, namely, the Ob-Ugrians and the Siberian Tatars (the Tobolo-Irtysh group). The chronological framework of the research covers the whole period of the existence of the Russian empire (1721-1917).

There are quite a few works focused on the introduction of monetary circulation among the indigenous peoples of Yugra. The history of Siberian numismatics is described in Nikolay Konkov's monograph (2001) while other authors mainly investigate the issues of an exclu- 
sively non-monetary exchange (Mizgulin and Vychugzhanin 2010; Tsys 2015: 595-601 et al.). We think that the following subject matters remained understudied: the introduction of the monetary circulation in Yugra, the regulatory system, the causes of the failed implementation of the reform of 1769 , and also historical evaluation of these events.

The response of the Yugra indigenous peoples to the Russian empire colonization policy is interesting in the context of a comparative analysis between Siberia and North America ('aboriginals of the North of Russia Native Americans') since in the course of territory colonization similar processes were observed (Kerner 1973; Sumner 1947; Lantzeff 1973; Akimov 2010; Nikitin and Petrov 2012). The scholars studying the issue with application of Frederick Turner's Frontier Concept, for the time being have not compared the syncretic phenomena in aboriginal cultures of Siberia and North America, but studied the subject locally, relative to Siberia (Radlov 1885; Bakhrushin 1935; Slezkine 1994; Selezyov and Seleznyova 2004; Korusenko 2012; Sokolova 2012) and North America (Stingle 1978; Brasseur 1978; White 2006; Prokhorchik and Chikalova 2016 et al.). The comparative analysis demonstrates that religious syncretism in the Siberian Tatars' culture had more diversified and profound evidence than in the culture of American Indians. One of the authors of the present article in her thesis research defined the reason for this phenomenon in the implementation of the national policy oriented at transformation of the Siberian Tatars culture (Bortnikova 2014). As opposed to the Christian missionary activities in the USA, the similar policy in Siberia was conducted via indirect forms; it was implemented under the cover of the 'green banner of Allah' and was a greater success.

Already in the eighteenth century the so-called 'Tobolsk type of culture' evolved as the intertwinement of multidirectional traditions of Russia, Europe, Asia and the aboriginal North resulting from complicated historical processes (Yarkov and Markdorf 2010: 226). The study of the cultural landscape of Siberia discovered the presence of a new form of multiculturalism, unknown in the Western civilization. This is not simply a pattern of peaceful coexistence of various cultures, but a unique phenomenon that appeared as a result of their fusion. In the Christian Tatars' world view, for example, this led to a synthesis of the Orthodox and Islamic perceptions, and expressed in the presence of Orthodox shamails (in this case, without images of living beings, as is customary in the Islamic faith) and in understanding and creation of Orthodox authentic sources on the basis of Quran etc. (Naumenko et al. 2016: 594-599). 


\section{THE OB-UGRIANS AND SIBERIAN TATARS WITHIN THE CULTURAL LANDSCAPE OF WESTERN SIBERIA}

The Khanty and Mansi who are hunters, fishermen and reindeer herders, confessing shamanism represent indigenous peoples and have been residing in the territory of Yugra since ancient times. They belong to the Ural race or as a specific Ural anthropological type - to the Western Siberian race (Bagashchev 2000: 281). In the first millennium A.D. the climate in Yugra was warm and dry, and that gave a boost to business activity processes; in the sixth - ninth centuries the Ob-Ugrians achieved the statehood level; thus, the first principalities emerged between the tenth and thirteenth centuries. In the second half of the sixteenth century they transformed into large political alliances headed by the Pelym Principality, whose capital was situated in the place of the conflux of the rivers Pelym and Tavda (Ivanov 1998: 33). The inhabitants of principalities supplied the world market not only with furs and skins, but also with mammoth tusks, fish-glue, walrus tusk, falcons for hunting, slaves and other commodities; they bought metal handicrafts, silver tableware, jewellery, etc. (Baranov and Gorshkov 1999: 71-72).

The trade was carried out through intermediaries, namely, the Volga Bulgars, and starting from the thirteenth century - with the help of Siberian Tatars $^{2}$ who would later also found their principalities, the most important of which was the Khanate of Sibir. The Ob-Ugrians paid tribute to Siberian Tatars in the form of sables and other furs. Since the twelfth century there were attempts to conquer the Khanty and Mansi on the part of Novgorod merchants, who from time to time got underway to Yugra to make military campaigns, and as a rule, won the principalities and laid them under tribute (Zapadnov 2005: 12). Joining Siberia to Russia and the defeat of the Sibir Khanate at the end of the sixteenth century strengthened the practice of collecting tribute (yasak), but destroyed the already emerged goods/money relationship both with Siberian Tatars and with Ob-Ugrians.

The distinctive feature of the intellectual culture of the Khanty and Mansi is an extraordinary steadiness of traditional assumptions, worldview paradigms and life philosophy, and all these were determined to a large extent, by the climate: only a precise adherence to the ancestor practices and experience could ensure surviving in rough environments of a long winter. The major elements of this system are tolerance, capability to live in harmony with the outside world, that is, nature, people and regime, as well as the expressed humanistic basis of attitudes towards life.

The Siberian Tatars represent the immediate anthropological, cultural and historical descendants of the Ob-Ugrians (Korusenko 1998: 8890). They preserved the basic components of the spiritual and intellectual 
culture of the Khanty and Mansi; the steadiness of these paradigms is so great that Islam, accepted by the Tatars at the end of the fourteenth century failed to become the prevailing religion for a long time; it just merged with shamanism, having created a unique syncretic phenomenon. Among its manifestations are shaman idols and dolls - ittermas (puppets of the diseased), the traditional Khanty festivities, folk traditions, totems, etc. One should give a special attention to the completely developed cult of a bear which is common for the Ob-Ugrians as well.

Both peoples lived in similar economic activity system and had common ancient gods which at the same time did not prevent the Tatars from confessing Islam. In the field of goods/money relationship both peoples used goods (mainly fish and also skins of squirrels, sables and other animals) as an equivalent of exchange. Thus, both $\mathrm{Ob}$ Ugrians and Siberian Tatars were of similar value for the imperial regime as they procured furs that filled the State treasury with money. Therefore, the representatives of the state authorities would more often identify them under the common name of 'non-Russians' and applied a common economic policy to both peoples.

The difference between the Ob-Ugrians and Siberian Tatars laid in the fact that the former were classic carriers of aboriginal culture which included all essential components both in form and in content: mythology, animism, customs etc. (Tylor 1989: 121, 149, 457), and the latter, possessing the same cultural external characteristics, initially were formed as representatives of intercultural version of life activity. This version was not simply a combination of shaman and Muslim views, but an absolutely new syncretic phenomenon. Until the late eighteenth century, when Islam penetrated deeply into the life of Siberian Tatars, one may speak about not even syncretism, but about multiculturalism that influenced all spheres of culture of Siberian Tatars. Among the multicultural views of the kind, for instance, there was conception of Islam as the most tolerant religion in the world but in an original way, that is to say, both shaman idols and Orthodox culture elements might be found in it (Bortnikova 2014: 173-182). Such an approach facilitated an easier adaptation of the nation to the imperial policy in general; hence the results of the economic experiments which influenced the fates of Ob-Ugrians and Siberian Tatars, differed to a greater extent.

\section{THE STATE MONETARY POLICY IN THE TERRITORY OF YUGRA AND ITS OUTCOMES}

In the Russian empire the monetary policy in relation to the Yugra peoples was implemented in several stages.

The first stage unfolded between the years 1721 and 1766, starting from the foundation of the empire to the beginning of the monetary re- 
form of Catherine II in the territory of Western Siberia. The major outlines of the new policy were formulated well before the establishment of the empire since the preparation for the Northern war required certain changes in relations with the peoples paying tribute (yasak). In 1695 and 1697, Peter the Great signed the documents concerning the nonRussians residing in Western Siberia. The tsar decrees took them under his personal protection and introduced capital punishment for everyone, who will 'inflict resentments to them', torture, bring to ruin, sell wine etc.: 'And it is prohibited to buy their wives and children, and to take them to one's farmstead or to baptize and to bring them away from Siberia to Russia or send them away with anybody' (Complete Code ${ }^{3}$ 1830: 372). Thus, the point was to preserve the traditional style of life of the Ob-Ugrians and Tatars who paid yasak, although the reasons for this decision were purely economic. For the first time in official papers of the imperial regime a settlement payment was fixed for fur skins by money: 'And the service-men, who will start bringing furs from new lands and will not hold back, should be given money for furs from the monarchic treasury' (Konev 1999: 61). In 1700 Peter the Great commenced a monetary reform, which facilitated the distribution of money when making payments for furs in Siberia. The practice established under Peter the Great to levy tribute (yasak), mainly by money, and not only by skins, is also confirmed in the Decree of Peter II, published in 1727 (Complete Code 1830: 819-821).

Meanwhile, these are Siberian Tatars, and not Ob-Ugrians, who got involved into the goods/money relationship. The historical memory, related to the flourishing Siberian Khanate, which was on the Great Silk Road from China, established favorable preconditions for using the monetary system. More than that, there was observed a fusion of the Tatars with Siberian Bukharans, representatives of Central Asia from Urgench, Bukhara, Samarkand and other large trade cities. Their number in the region was constantly growing: in 1782 there were 3,429 people, in 1834 - 5,604 people, in 1858 - 6,569 people, in $1897-6,720$ people (Korusenko and Tomilov 2011: 179). The Siberian authorities allocated lands to them in settlements common with Siberian Tatars, which objectively resulted in everyday contacts both at the mundane and personal levels. The Siberian Bukharans were prohibited to make settlements in other places. Thus, the gradual fusion of the two peoples initially was based on the state's administrative resources.

The fusion defined new borderlines of the regional culture. The Siberian Bukharans eliminated a hijab (Yarkov and Garifullin 2004: 25), and some elements of their culture were replaced by the elements specific to Western Siberia. This manifested in the shape of mosques, 
ornaments, clothes, etc. For example, in the village of Yembayevo where Siberian Bukharans initially prevailed in number, on the fronton of the mosque built in 1888 near the half-moon there is a picture of David's Hexagram Star. This element was borrowed from the culture of Siberian Tatars. Thus, the internal part of the Star represents a hexagon, which is sacral in their archaic views and is present practically everywhere, for example, minarets and mazars (sacred mausoleums of Sufi sheikhs-missionaries) have a hexagon form (Bortnikova 2012: 12).

In the meantime, these were exactly Siberian Bukharans who reinforced the Muslim element in the culture of Siberian Tatars. In particular, they brought from Mecca to Western Siberia a glass capsule with a hair of the Prophet Mohammed, created the first in the region handwritten Quran (TOKM ${ }^{4}$ No 19063), taught Tatars the arts of embroidered Muslim shamail, etc. Initially they appeared in Siberia as merchants and thus, having the Russian state patronage, they involved Siberian Tatars in a dynamic goods/money relationship. The Siberian Bukharans brought caravans with silk and satin fabrics, Chinese cookware, dried fruit, spice, and precious jewels etc., from China and Central Asia and that enhanced the money turnover and limited the trade exchange option, which used to be typical for the Siberian Tatars.

Besides, the mixed Russian and Tatar settlements, proximity of habitations to towns and influence of Bukharans on Siberian Tatars prompted the latter to depart from hunting and fishing trades as a basic type of economic activities, and develop husbandry. While in 1686 the tribute Tatars of just one district cultivated 652 dessiatines (land measure equivalent to 2.7 acres) of land, ${ }^{5}$ then in 1780 they ploughed already more than 14 thousand dessiatines, which amounted to 19.3 per cent of all agricultural lands of the district (Garifullin 2000: 54). In this situation the role of money also increased. The exchange trade of the Ob-Ugrians was reduced to fur skins, fish and the narrow list of other goods, whereas Siberian Tatars had this range grown much higher, including agricultural products (Idem.).

At the same time the Ob-Ugrians lived in a stable traditional cultural environment which prevented them from entering the state legal framework of the country and their merchandise exchange failed (Konev 1995: 50). The Khanty and Mansi still preferred an exchange in kind but not money. In the holdings of the Museum of Nature and a Man there are preserved ancient ceremonial treasure-troves of the Khanty and Mansi, while the Russian coins dated Peter the Great period are few (Coins... 2009: 12). The preserved exchange in kind resulted in the cruelest exploitation of the peoples of the North on the 
part of Russian businessmen; in order to wheedle 'furs' all possible means were used. By the 1760s, the operations with furs in Yugra had almost totally moved to shadow economy (Pesterev 2005: 100); the public treasury was losing huge revenues, and the public authorities failed to stop this process. Catherine II tried to change the situation.

The second stage of implementation of the state monetary policy in Yugra dates to 1766-1796 and it lasted during nearly the whole reign of Catherine II. Here the monetary reform was launched three years earlier than in European Russia when in 1766 in the district of Yekaterinburg they started minting special copper coins (with nominal value from a quarter-kopeck to 10 kopeck) intended for Siberia (Coins... 2009: 5). Their size was less than a standard one and had a picture of sables which used to be a part of the Siberian coat of arms. In 1769 paper money were brought into circulation in Russia, and in 1776 the only counting house in Western Siberia was open in Tobolsk, where one could exchange paper money to copper coins (RGADA. F.19. Op.1. D.419. Past 1. L.41). There were created conditions for the development of currency circulation, namely: the circulation of Siberian coins in European Russia was prohibited, and soon after the start of the reform another mint, called the Suzunskiy Mint, was established (Coins... 2009: 5).

Meanwhile, the native peoples of Yugra would use Imperial money for some different purposes than it was intended; yet, that phenomenon was spread to various extents in different regions. While the Siberian Tatars used coins only to make adornments serving as amulets (necklaces, earrings and other items) and preserved most part of money for trade operations, the Ob Ugrians used coins mainly for ceremonial purposes. They collected coins in spacious treasure-troves at pagan temples where shamanistic rituals were held; and the coins served as a means of emergency aid to countrymen. It was allowed to take money from the gods for an indefinite period, and also without interest. The return of the debt was secured by religious consciousness. In 1904 Konstantin Nossilov, who explored Yugra, discovered one of such old-time treasuries:

On the neck of the idol there was a whole load of expensive, ancient and new, silk kerchiefs, tied in a woman style; in the corners of these handkerchiefs there were so many silver ancient coins of Catherine II period as well as new ones, that one could fill a good dish with them. The warm fur dressing-gown of sables was also laden with shawls, patches of satin and various pieces of fabrics of all colors, in the corners of which silver had already been wrapped. However, when we took the fur coat made of deerskin off the idol, we discovered a real treas- 
ury of silver. It fell out of all the holes of the ancient fabric, satin and silk, with which the idol's body was enwrapped. We would start to unwrap it, pull one piece after another ..., and the silver, time darkened, as rain would fall around us on the floor of a small granary.

Good Heavens, how many goods and chattels, what a great amount of the Voguls' labor money is kept in this idol! Here you can find old rubles, and fifty-kopeck pieces, and Polish zlotys, and quarters and coins of all the times of our Empire. And all this knocked falling on the floor of a small granary and rolling into its corners. It seemed to me that I saw all this in a dream. It was impossible to touch the decomposed fabric, lest that a coin would not drop from it; but I was even more surprised when together with the silver I saw small silver cups, full of coins. I grasped one and carefully examined it. That was a delicate, not Russian made piece of work. In its bottom there were pictures of dragons, some horrible birds and animals, something familiar, resembling to Egypt and Persia (Nossilov 1904: 90-91).

The usage of coins was not initially regulated by shamanism, which was actually more a life philosophy than a religion. Shamanism neither touched upon the money circulation in general, nor prohibited it (Mikhaylovskiy 2005: 62). Yet, there is the following rule in shamanism: 'The property, which is brought to the gods, may be taken by those in need and be returned by an Ostyak in a "good" year' (Mizgulin and Vychugzhanin 2009: 243). When the monetary circulation was introduced, the number of Russian coins in precious gifts to the gods sharply increased and that was caused by a number of factors of religious, cultural and historical nature.

First of all, there was a picture of heraldic eagle on coins, which together with a bear represented the major characters in the Ob-Ugrian religion. In the Khanty folklore, in particular, there exist several related patterns: a) 'a man went hunting, he wanted to shoot an eagle seven times; the eagle asked not to frighten him but to kill at once'; and b) 'the man brought the wounded eagle home and healed it up' etc. (Kim 2016). The Voguls would sometimes just leave an eagle on some coins, while the other side would be glued with paper. Such exhibit items can be found in the Museum of Nature and a Man (Russkinskaya Museum of Natural and Human History in Yugra. № XM 628 'Not identified'; XM 633/1 EM etc.). Coins with the imperial eagle on the obverse were used as faces for little gods for ceremonial purposes. If coins did not fit into the intended trench shelter, they were decreased in diameter, that is, cut down or filed off (Russkinskaya Museum of Natu- 
ral and Human History in Yugra, № XM 6194 EM; XM 621/5 'Spilen'; XM 615/2 CM and others).

Coins with an eagle outwards were glued to sacred documents (there are numerous exhibit items of the kind, see Russkinskaya Museum of Natural and Human History in Yugra, № XM 593 EM-HM; XM 605/1; EM-IK XM 605/2 EM-IK and others). The paper money introduced by Catherine II, were considered as sacred papers ('Charters'). The peoples which had not created a single written source by that time, had a sacral attitude towards documents ('Charters') in general. As noted by A. Ya. Chesnov, this idea '...penetrated the whole worldview of the Khanty peoples. Here the presiding deity gives to a man a "Golden Charter" and other instructions in written form. A man, captured by the Forest Tsar, would be saved by the fact that he had the Charter with him (just by its very presence)' etc. (Chesnov 1998: 360). The paper money, introduced by Catherine II, also had a picture of an eagle on the surface, therefore the Ob-Ugrians always tended to use them as talismans withdrawing them from commerce.

The metal, used for minting Siberian coins, also was of sacral value for the indigenous peoples (the presiding deity of Torum, in particular, was thought to have a 'seven-storied house with golden chimneystacks'). Golden coins are not rare in treasuries of the Khanty; in particular, Kazym Goddess, which was brought to the museum from a sacral place in 1961, had 96 golden coins (Moldanova 2016). The Ob Ugrians consider silver as one of the most sacral metals, and that is connected, in the first instance, with its 'white' color (clean, light), as well as with the tinkle created by silver and frightening the evil spirits away (Lukina 1990: 82). According to Gondatti, there were 'tens of poods [pood is a unit of mass equal to $16 \mathrm{~kg}$ ] of old silver' found at holy places of the Khanty and Mansi' (Gondatti 1886: 52). Red copper was a sacral metal too, since that color meant life in the culture of the North peoples. The Siberian copper, used for minting local coins, contained many alloys of gold and silver (thus, the weight of coins was smaller than in European Russia), consequently, they perfectly met the aboriginals' perceptions about sacrificial gifts to their gods.

During Catherine II reign and later the flow of coins to the region increased, the ways the coins could be offered to the gods as a tribute became more diversified. Along with the ways mentioned above, coins were offered in some other ways: 1) they were thrown to the hillside of the Holy Mountain or stuck edge-side into the ground; in case of a stony soil people sometimes had to force them in the ground, thus, causing their deformation. Such exhibition samples are kept in the Museum of Natural and Human History (Russkinskaya Museum of Natural and 
Human History in Yugra, № XM 598 /2 KM - AM; XM 1861/3 CM; XM $624 \mathrm{CM}$ and others); 2) the coins could be stuck on the Holy larch: one can find the coins with traces of a special glue (Ibid., № XM 609/2 EM-FX and others; 3) coins were used for a kind of brick-laying. On the Shaman Mountain not far from Khanty-Mansiysk there is such a construction made of seven rows of coins; in the bottom row there were coins with the least denomination, and in the upper one there were coins with the biggest denomination (Coins... 2009: 11). This emphasized the meaning of the number 'seven' in the Khanty's and Mansi's cultures; in particular, shamanism speaks about 'the sky of seven abysses', where the Gods go down from (Lukina 1990: 80); 4) coins were enveloped into the birch bark, which separated the alive from the deceased (Kulemzin and Lukina 2016); and 5) coins were put in tree hollows of the Holy larches. On the Shaman Mountain just outside Surgut there were ten Holy larches (Coins... 2009: 11).

Thus, the monetary reform initiated by Catherine II failed to achieve the set objectives but managed to partially change the aboriginals' religious ceremonies. The animal skins were still used as an exchange equivalent, and their paws served as 'coins to exchange' (Tsys 2015: 601). By that time, there had been already processed the results of new ethnographic expeditions to Siberia (among its participants were P. S. Pallas, I. P. Falk, and I. I. Georgi) and the works of G. F. Miller had been republished and described the aboriginal customs in detail. So it became clear that the prospects of introduction of a monetary system in the North of Russian Empire were vague. Besides, all explorers emphasized a peaceful nature of the Voguls and Ostyaks, the absence of political conflicts among them and their religious tolerance, and that complied with a new policy of Catherine II to establish confessional tolerance in Russia (Bortnikova 2016: 17).

In 1788 the Tobolsk counting-house was closed and the governmental policy towards the aboriginals of the Russian North changed along with their stopped Christianization. According to the Decree dated March 06, 1789 'the non-Russian chiefs' from family representatives were entrusted with 'management of the closest nomad camps and settlements' etc. (Konev 1995: 53). A number of regulatory acts were adopted; they protected aboriginals from arbitrary treatment on the part of the Russians while the establishment of new administrative arrangements revealed their social organization and shamanistic perceptions. Thus, Catherine II set a course for the preservation of the Ob-Ugrian cultural authenticity.

The situation with the Siberian Tatars was different. Their culture still contained a vast layer of shamanism, included into regional views 
about Islam, and that provided Catherine II with an opportunity to carry out an innovatory experiment. It was planned not to preserve the Siberian Tatars' unique culture but to expose it to a larger deformation by fixing shamanistic ideas in it and introducing Christian components without allowing the Islamic constituent to develop (Bortnikova 2014: 47). The reform was successful as far as the state power is concerned; irrespective of the project considered as doubtful as regards democracy and religious freedom, this measure promoted harmonization of relations between the Siberian Tatars and other peoples in the region. In particular, according to some evidences in 1841 , ' $\ldots$.. some Muslims visit the church, putting candles in front of icons. During the Cross Procession they together with Russians go to the prayer place ...' (Yarkov 2007: 91). The resulting syncretism, which was gaining the features of multiculturalism, would be reflected in the religious decorative and applied arts of the Siberian Tatars which was in accordance with Orthodox arts in the set of major components while the contents combined Islamic and shamanic arts with the elements of Tengrism (Bortnikova 2014: 177).

The third stage of the monetary reform in Yugra covers the period from the late eighteenth century (the death of Catherine II) to the end of the nineteenth century. Its basic course was the cruelest exploitation of the Ob-Ugrians which paved the way to the destruction of their culture. The state failed to solve the problem of the aboriginals' adaptation to the Russian economic reality. The only achievement was the arrangement of large fairs in Surgut for trade with the Ob-Ugrians; however, the latter would still prefer to exchange in kind while any protection from the arbitrary treatment of merchants was completely absent. For example, 'a boat would cost the equivalent of the amount of muksuns it can comprise when completely filled with fish; for a boiler one would pay as much pure fish oil as the boiler would contain' etc. (ProTown N.d.). In the 1820 s, the tribute in furs for the ObUgrians (as well as Siberian Tatars) increased by nearly 300 per cent if compared with practices under Catherine II in 1763. According to the information from the officials of the Tobolsk Treasury Chamber for 1828, under Catherine II 'the non-Russians were much more prosperous than nowadays.' Thus, in the early nineteenth century the aboriginals paid from 40 to 60 per cent of their income in 'good years' as a tribute (yasak), and paying taxes in 'bad hunting and fishing years' resulted in famine, which, for example, from 1810 to 1817 occurred four times (Pro Town N.d.). Therefore, the state did not regulate the situation at all, and till the end of the nineteenth century there were no improvement observed in the life of the Ob-Ugrians. Money was still 
used in religious ceremonies, and was not perceived as a necessary element of economic realities.

As for the Siberian Tatars, in the late nineteenth century the goods/money relationship among them, on the contrary, reached the stage of prosperity. For example, the trade circulation among the nomads of the village of Yembayevo of the Tyumen district exceeded 200 thousand rubles per year; in the village of Turayevo it surpassed 150 thousand rubles, etc. There appeared wealthy merchantspatrons, among them one may recall the Seydukovs, the Chenbayevs, Bagautdin and others (Garifullin 2000: 81-82).

The fourth stage of the money circulation mainstreaming policy of the state in Yugra dates back to the late nineteenth - early twentieth centuries: the National Bank departments and other institutions emerged in the region (Vychugzhanin and Otradnykh 2004: 73). During this period the events involving the Ob-Ugrians required prompt state interference because of an ongoing powerful process of the destruction of those humanistic components of the indigenous culture, which constituted its core value. The banking system prevailed in affecting them adversely. As Nossilov recollects,

...the Voguls were eventually tempted by a large credit, opened with the trade of Mr. Sibiryakov... I was told that the Voguls of just one river Sosva had already owed to Mr. Sibiryakov more than one dozen thousand rubles, whereas all their property taken together did not cost even ten thousand rubles, and whereas all of them, taken together, were unable to pay with their crafts even five thousand rubles per year... They consider Mr. Sibiryakov as a rich man; and a rich man, as they understand that, must feed and dress them up on credit. Thus they demand him all this every year, when he passes by, and, apparently, they ask in such a way that it is beyond his power to refuse them, although this deal is at odds with his commercial viewpoints ... As long as the Voguls do not pay even a tenth part of their debts, then he should raise prices for his goods whether he likes it or not ... It goes without saying that such expensiveness ruins Voguls to a greater extent ... In the region I was told that Voguls from honest debtors now transformed into obvious swindlers, that their exchange became already dodgy, and that they were thieves ... (Nossilov 1904: 152-153).

At the threshold of the nineteenth - the early twentieth centuries the Ob-Ugrians failed to adapt to the development of the goods/money rela- 
tionship in the region. There is a collection of coins conserved in the Museum of Nature and Human of the Surgut district of the Yugra, which came from pagan temples of the Ob-Ugrians. The arrangement of these coins according to several chronological periods enables to track the frequency of using imperial money in ceremonial purposes (Table).

Arrangement of coins from the Ob Ugrian pagan temples

\begin{tabular}{|c|c|c|c|c|c|c|c|c|c|c|}
\hline \multirow{2}{*}{$\begin{array}{c}\text { Years of } \\
\text { minting } \\
\text { coins }\end{array}$} & \multicolumn{7}{|c|}{ Readable mint (coins, pes.) } & \multirow[b]{2}{*}{ 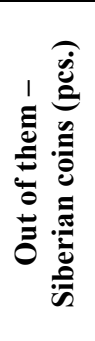 } & \multirow[b]{2}{*}{ 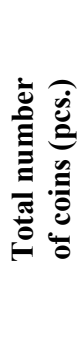 } & \multirow[b]{2}{*}{ 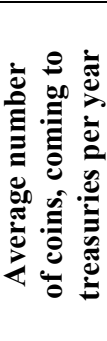 } \\
\hline & 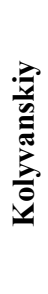 & 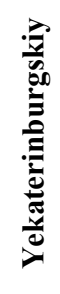 & 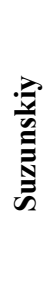 & 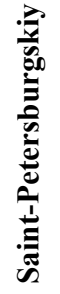 & 齐 & 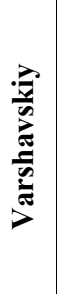 & 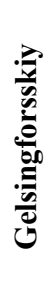 & & & \\
\hline $1721-1765$ & & 2 & & 2 & & & & & 18 & 0.4 \\
\hline $1766-1796$ & 5 & 12 & & 2 & 2 & & & 18 & 40 & 1.3 \\
\hline $1797-1860$ & 30 & 48 & 35 & 20 & 9 & 6 & & & 148 & 2.3 \\
\hline $1861-1895$ & & 150 & & 48 & & & & & 202 & 5.7 \\
\hline 1896-1916 & & & & 96 & & & 2 & & 151 & 13.7 \\
\hline $\begin{array}{l}\text { Total for the } \\
\text { whole period } \\
(1721-1916)\end{array}$ & 35 & 212 & 35 & 168 & 11 & 6 & 2 & 18 & 559 & 2.9 \\
\hline
\end{tabular}

Source: Coins of the Russian Empire ... 2009.

As the Table shows the dynamics of money accumulation in the Ugrian treasuries was directly proportional to the development of the goods/money relationship in the region; in particular, the more and stronger developed the market, the larger amount of money came to shamanistic pagan temples. Even with the account of possible incompleteness of data, in particular, the amount of the 'loan' of coins by moneymakers themselves, robberies from pagan temples, presence of unexamined exhibit items in the museum etc., the tendency is obviously clear. More than that, the Khanty and Mansi would bring the money to their gods, which they considered uncommon, particularly, the coins of Anninskiy, Gelsingforsskiy and Varshavskiy mints. One of the Varshavskiy coins appeared to be a copy of the original that 
was present there too; probably, it was made intentionally for sacrifice or 'pushed off' to Khanty by unfair purchasers of furs.

The money was not the only valuables in such treasuries. According to archeological data of N. V. Fedorova, Yugra '... was imagined by its explorers as a storehouses where in ancient holy places the following items were hidden for centuries: dishes with the images of Sassanid tsars, Sogdian floriated mugs and jugs with Zoroastrian pantheon personages, Islamic silver bottles and trays with inscriptions of velleities' (Fedorova 2002: 17). In 1897 the Archeological Mission bought one of such eighteenth-century golden dishes with Arabic inscriptions in Oriental style from the aboriginals at a token price for Tobolsk Provincial Museum (State Archive of the Tyumen Region. F. 1731. Op. 1. D. 17. L. 4). Although the goods/money relationship in the region flourished, the Ob-Ugrians still hardly knew even an approximate price of this item.

On the whole, the attempts to get the Ob-Ugrians involved in financial relations of the Russian Empire resulted in the conflict not between cultures but between economic systems. For centuries the Khanty and Mansi had existed with reciprocal economy, typical for many traditional societies. Its main peculiarity was the absence of the purpose to get profit, whereas economic relationships were regulated on the basis of religious paradigms, customs and ethics. Reciprocity, being the major economic principle of the Ob-Ugrians, ensured a sustainable preservation of cultural components while the elimination of this principle caused weakening and even destruction of traditional views.

The Siberian Tatars also had to exist in a peculiar economic environment. In their case that was the Islamic economy, which would confront the national economic system of the Orthodox Russia. Nevertheless, the policy directed at developing of an intercultural worldview among the Siberian Tatars promoted the re-consideration of the economic principles within Islam, which helped to easily fit the Russian reality.

In particular, Islam presupposes three corner-stone foundations of economic relationships. First of all, it is the prohibition of riba (borrowing rate). In Orthodox Russia the historically 'disreputable' field of usury was the domain of the non-Christians - the Jewish people and Moslems, and in case of absolute application of this postulate the latter were beyond the Russian banking system and that did not meet interests of the country's economic development. In fact, among the Moslems of Tobolsk Province there were no bankers at all (Vychugzhanin and Otradnykh 2004: 57-66). After the adoption of the usury law in 1893, the Islamic prohibition of riba would fit the ethic postu- 
lates of the Orthodox state. Secondly, the Islamic economy presupposes the creation of an adequate taxation system whose central elements were a poor-due Zakat and the principle of confession (Moslems, recent converts, people of different faiths). For the Siberian Tatars the poor-due Zakat as an obligatory donation to the Moslems in need completely complied with the Christian rule of tribute. In Tobolsk Province (and in contemporary Tyumen region) this principle would transform so that the poor-due Zakat was intended for everyone in need, notwithstanding their religious identity. For example, a traditional Sabbatical sacrificial slaughter of a lamb near mosques is accompanied with giving meat to everyone who comes. This absolutely meets Christian principles, according to which alms should not apply only for the Christians. Another tax principle of the Islamic economy, namely, the dependence of the amount and types of a tax on the religious identity, was also in agreement with the ideology of the Orthodox state. Thus in Russia levying a supplementary tax on the representatives of other religions was historically in practice. So, it turned out that they 'bought' the right of faith for themselves (e.g., 'people who pay double tribute'). The question was only in interpretation of those regulations, appropriate for the state.

Thus, the historical fates of two closely-related peoples diverged. While the Siberian Tatars entered a new stage of their development, the Ob-Ugrians would find themselves in the situation of dying out and decline of their culture. The decreasing population numbers can be illustrated by the results of population census: in 1897 in Tobolsk Province there resided 19,018 Khanty and 4,790 Mansi while in 1926 there remained 13,696 and 1996 respectively (Karabulatova 2007: 209, 338). The number of the Siberian Tatars, on the contrary, increased. Thus, in 1897 there were 56,957 people (Karabulatova 2007: 299), in 1926 - 90 thousand people (Tychinskikh 2011: 130).

The history of introducing the money circulation in Yugra puts one more question: the ability of the Ob-Ugrians to adapt to environment of the goal-oriented state influence, to which the Siberian Tatars were exposed. The answer is evident judging from the results of compulsory Russification of indigenous peoples of the North of Russia during the Soviet period. In the 1920s the 'campaign against illiteracy' was launched, and an alphabet was created for the Ob-Ugrians as well as $\mathrm{ABC}$ books and study materials. The aboriginals' children were forcefully taken away from their families to study the Russian language at boarding schools (Yeremeyeva 2004: 94-95). Afterwards the system of merging of the Ob-Ugrians with Russians through mixed marriages was elaborated: for example, they were provided apartments equipped 
with modern conveniences in a top priority way. Children from mixed marriages conserved the status of indigenous small-numbered peoples of the North, and, accordingly, had some other privileges, namely, education opportunities at Universities, free of charge equipped houses in villages helping to adapt the aboriginals to sedentary life etc.

The result of Russification of the Ob-Ugrians met expectations. New generations grew up in the intercultural environment and preserved only partial ancestral knowledge so they were unable to follow their traditional culture principles. Among the Ob-Ugrians there appeared scientists, public men, managers of the highest level, artists and writers (Bortnikova 2014: 116-117). The Khanty treasuries in pagan temples still contained Soviet money, but their percentage ratio to imperial money was considerably lower. Among the Ob-Ugrians the share of urban population significantly grew; for instance, the urban population share among the Mansi in 1983 was 45.7 per cent. The Russification led to the following results: according to the 1989 data just 36.7 per cent of the Mansi spoke their native language (Sokolova 2000: 173). Besides, the demographic increase was observed: while in 1926 the number of the Ob-Ugrians was 15,692 people (Karabulatova 2007: 209, 338), in 1989 they were about 30,000 people (Sokolova 2000: 169 ).

The revealed trends find the brightest expression if we compare them with the history of the Native Indians. In the course of colonization as a result of active missionary activities, syncretism began to develop in the Indians' religion with elements borrowed from the European culture; there also took place a transition from natural economy to market relationships (Prokhorchik and Chikalova 2016: 114). These changes became to a large extent the result of violence, when aboriginals were left no choice: in particular, during the missionary war of 1675-1676 only 2,500 out of 4,000 Indians survived, who inhabited the lands conquered by the English (Prokhorchik and Chikalova 2016: 113). However, the adaptation to new reality proceeded painfully; the number of Indians decreased, and there was no cultural merging observed. That was due to the conditions and means of colonization which were different from those applied in Siberia.

The cultural space of Siberia even before the mass migration of Russians was distinguished by a complicated landscape where differrent world religions would intertwine. At the very beginning that created a particular environment of intercultural interaction. Unlike the American colonizers, the Russian empire never resorted to destroying indigenous nationalities or ousting them from their traditional territories. The goal of the state was to preserve the authenticity of the pe- 
oples of the North; and when it came to cultural transformation then it was carried out by indirect methods, reasoned by 'public welfare' of the Russian state. Consequently, the forced Christianization was infrequent and temporal and had a local nature. These were exactly the factors, which differentiated the colonization of Siberia from the Northern America and caused various phenomena in cultural environment of the two regions.

\section{CONCLUSIONS}

The introduction of money circulation to the Ob-Ugrians' life failed to bring the expected results since this process revealed some factors unpredictable at that time which the state power ignored. It is obvious that the development of different peoples in similar living circumstances can provoke different response to the state policy, and that is related to peculiarities of cultural and historical environment of these peoples. The multicultural phenomena turned to dominate in this process.

The new version of multiculturalism is a consequence of cultural fusion. However, a nation can borrow foreign culture only in three cases: first, if this helps to satisfy the long-existing ethic, economic or political needs; second, if an objective process of interactions between cultures is underway as a result of a long-lasting experience of enforced joint life-sustaining activities; and third, in the case of violence on the part of another culture representatives. The establishment of multicultural phenomena among the Siberian Tatars (both Christians and Muslims) involved all these trends, namely: the nation building processes evoked the demand for changing the political organization and lifestyle, which built the basis for accepting Islam in the fourteenth century; the long-term cultural relationships with the Siberian Bukharans and never interrupting relationships with the Ob Ugrians promoted the syncretism of cultures, and violent Christianization completed the formation of multicultural phenomena.

In this context, the Russian empire's policy of non-interference into the Ob-Ugrian culture can be perceived as the policy of its preservation and it has demonstrated that this path is a deadlock and results in extinction of the peoples. On the contrary, the targeted impact upon the culture of the allied Siberian Tatars led to the emergence of a new national intercultural (with respect to the Russian empire - even multicultural) community, which can easily adapt to any conditions. However, such a result requires a willingness of the part of the nation itself which initially created a syncretic culture. The formation of multicultural phenomena with the Siberian Tatars proceeded in their territory with the lifestyle and moral framework common with other pe- 
oples, in the absence of democratic regime, when peoples had only the rights and opportunities defined by the state.

Nevertheless, a new form of multiculturalism has the right for existence. As seen from the comparative experience of the development of the Ob Ugrians and Siberian Tatars, it is exactly the above-mentioned form that represents the basis and ensures successful adaptation of a nation to challenging conditions of history.

\section{NOTES}

* The present study has been supported by the grant of the President of the Russian Federation for the young scientists (MK-3655.2019.6).

${ }^{1}$ Shamail is wall painting of a religious value containing extracts from Koran. It is specific only for Islam.

${ }^{2}$ Dating of formation of Siberian Tatars as an ethnos is open to discussion, however, this issue is not a research subject of the present article.

${ }^{3}$ Complete Code of Laws of the Russian Empire. Vol. III. St.-Petersburg, 1830. No 1594.

${ }^{4}$ Tyumen Regional Museum of Local Lore.

${ }^{5}$ Dessiatine is a land measure equivalent to 2.7 acres.

\section{REFERENCES}

Akimov, Yu. G. 2010. North America and Siberia at the End of $16^{\text {th }}-$ the middle of the $18^{\text {th }}$ Century. An Essay of Comparative History of Colonization. St.-Petersburg: St.-Petersburg State University. Original in Russian (Акимов, Ю. Г. Северная Америка и Сибирь в конще XVI-середине XVIII в. Очерк сравнительной истории колонизаций. Санкт-Петербург: СПбГУ).

Bagashchev, A. N. 2000. Ob Ugrians in the World Racial Classification. Entsiklopediya Khanty-Mansiyskogo avtonomnogo okruga. Vol. 2 (pp. 281-282). Khanty-Mansiysk: Sokrat. Original in Russian (Багащев, А. Н. Обские угры в мировой расовой классификации. Энциклопедия Ханты-Мансийского автономного округа. Т. 2 (с. 281-282). Ханты-Мансийск: Сократ).

Baranov, N. N., and Gorshkov, S. V. 1999. History of Khanty-Mansiysk Autonomous Okrug from Antiquity up to Now. Khanty-Mansiysk: Volot. Original in Russian (Баранов, Н. Н., Горшков, С. В. История Ханты-Мансийского автономного округа с древности до наших дней. Ханты-Мансийск: Волот).

Bakhrushin, S. V. 1935. Ostyak and Vogul Principalities in the 16-1 $7^{\text {th }}$ Centuries. Leningrad: Institute of North Peoples RAN. Original in Russian (Бахрушин, С. В. Остяикие и вогульские княжества в 16-17 вв. Л.: Институт народов Севера РАН).

Bortnikova, Yu. A. 2012. A Six-Pointed Star in the Art Culture of Western Siberia. Muslim-Info 2 (33): 12-12. Original in Russian (Бортникова, Ю. А. Шестиконечная звезда в художественной культуре Западной Сибири. Мyслим-Инфо 2 (33): 12-12).

Bortnikova, Yu. A. 2014. State Policy as Factor of Evolution of Muslim Art Culture of the Tyumen Region (1773-1991). Thesis of Candidate of Historical 
Sciences. Kemerovo. Original in Russian (Бортникова, Ю. А. Государственная политика как фактор эволюиии мусульманской художественной культуры Тюменского региона (1773-1991 г2.). Дис. ... канд. ист. наук. Кемерово).

Bortnikova, Yu. A., Naumenko, O. N., and Naumenko, E. E. 2016. Russia and Islam: State Policy on Formation of Muslim Tolerance in Western Siberia (1773-1917). Bylye gody 39 (1): 14-21. Original in Russian (Бортникова, Ю. А., Науменко, О. Н. и Науменко, Е. Е. Россия и Ислам: Государственная политика формирования толерантности мусульман в Западной Сибири. Былые годы 39 (1): 14-21).

Brasseur, T. J. K. 1978. Coastal Algonkian Peoples - the Peoples of the First Boundaries. In Averkieva, Yu. P. (ed.), North American Indians (pp. 75-87). Moscow: Progress. Original in Russian (Брассер, Т. Дж. К. Прибрежные алгонкины - народ первых рубежей. Североамериканские индейцы / ред. Ю. П. Аверкиева, с. 75-87. М.: «Прогресс»).

Chesnov, Ya. V. 1998. Lectures on Historical Ethnology. Moscow: Gardarika. Original in Russian (Чеснов, Я. В. Лекиии по исторической этнологии. М.: Гардарика).

Coins of the Russian Empire... 2009. Coins of the Russian Empire from the Nature and a Man Museum. Catalogue. Khanty-Mansiysk, Yekaterinburg: «Basco».

Fedorova, N. V. 2002. Byzantine Treasure of Ugrian Princes. Rodina 7: 17-20. Original in Russian (Федорова, Н. В. Византийское сокровище угорских князей. Родина 7: 17-20).

Garifullin, I. B. 2000. Sketches of History of the Tatar Population of the Tyumen Region. Tyumen: Anvarium. Original in Russian (Гарифуллин, И. Б. Очерки истории татарского населения Тюменской области. Тюмень: Анвариум).

Gondatti, N. L. 1886. Traces of Pagan Beliefs at Manzi. Trudy Etnograficheskogo otdeleniya $i$ obshchestva lyubitelei estestvoznaniya, antropologii $i$ etnografii pri Moskovskom universitete (pp. 49-73). Kniga 7. Moscow. In Russian (Гондатти, Н. Л. Следы языческих верований у маньзов. Труды этнографического Отделения и Общества любителей естествознания, антропологии и этнографии при Московском университете. (с. 49-73). Кн. 7. М.)

Ivanov, I. А. 1998. Yugra. Lyantor: Bojanych. Original in Russian (Иванов, И. А. Югра. Лянтор: Бояныч).

Karabulatova, I. S. (ed). 2007. Tyumen Region: People, Languages, Cultures. Tyumen: Express. Original in Russian (Карабулатова, И. С. (ред). Тюменская область: народы, языки, культуры. Тюмень: Экспресс).

Kerner, R. J. 1973. The Urge to the Sea. The Course of Russian History. The Role of Rivers, Portages, Ostrogs, Monasteries and Furs. Berkeley and Los Angeles: University of California Press.

Kim, A. A. 2016. Languages of the Ob and Yenisei Language Area. Folklore Textual Analysis. Original in Russian (Ким, А. А. Язылки Обско-Енисейского языкового ареала. Фольклорный анализ текстов. URL: http://siblang.tspu. $\mathrm{ru} /$ project09/RUSS/folklore.htm\#Человек и орел).

Konev, A. Yu. 1995. Indigenous Peoples of Northwest Siberia in a Management System of the Russian Empire (18 th - the Beginning of the $20^{\text {th }}$ Centuries). Moscow: IEA RAN. Original in Russian (Конев, А. Ю. Коренные народы 
Северо-Западной Сибири в административной системе Российской империи (XVIII - начало ХХ вв.). М.: ИЭА РАН).

Konev, A. Yu. (ed.) 1999. The Estate-Legal Status and Administrative Structure of Indigenous Peoples of Northwest Siberia (the End of the $16^{\text {th }}$ - the Beginning of the $20^{\text {th }}$ Centuries). The Collection of Legal Acts and Documents. Tyumen: IPOS SO RAN. Original in Russian (Конев, А. Ю. Сословноправовое положение и административное устройство коренных народов Северо-Западной Сибири (конеи: XVI - начало XX вв.). Сборник правовых актов и документов. Тюмень: ИПОС СО РАН).

Konkov, N. L. 2001. 'Monetary Circulation in Siberia': From the History of Numismatics and Monetary Circulation in Siberia. Tobolsk. Original in Russian (Коньков, Н. Л. Имеет хождение в Сибири: Из истории нумизматики и денежного обращения в Сибири. Тобольск).

Kulemzin, V. M., and Lukina, N. V. 1992. Get Acquainted: The Khanty. Novosibirsk: Nauka. Original in Russian (Кулемзин, В. М., Лукина, Н. В. Знакомьтесь: ханты. Новосибирск: Наука).

Korusenko, S. N. 1998. Genealogical Researches of the Siberian Tatars: Results and Prospects. Sibirskie tatary: Materialy I Sibirskogo mezhdunarodnogo simpoziuma 'Kul'turnoe nasledie narodov Zapadnoi Sibiri' (pp. 88-90). Omsk: Omsk State Pedagogical University. Original in Russian (Корусенко, C. H. Генеалогические исследования сибирских татар: итоги и перспективы. Сибирские татары: Материалы I Сибирского международного симпозиума «Культурное наследие народов Западной Сибири» (с. 88-90). Омск: Омский государственный педагогический университет).

Korusenko, S. N., and Tomilov, N. A. 2011. Tatars of Siberia in the $8^{\text {th }}-$ the Beginning of the $20^{\text {th }}$ Centuries: Resettlement, Number, Social Structure. Vestnik arkheologii, antropologii $i$ etnografii 2 (15): 177-185. Original in Russian (Корусенко, С. Н., Томилов, Н. А. 2011. Татары Сибири в XVIII - начале XX вв.: расселение, численность, социальная структура. Вестник археологии, антропологии и этнографии 2 (15): 177-185).

Korusenko, S. N. 2012. West Siberian Tatars: To the Problem of Ethnic and Regional Identity. Etnokul'turnye vzaimodeistviya v Evrazii: prostranstvennye $i$ istoricheskie konfiguratsii (pp. 91-109). Barnaul: Altai State Pedagogical University. Original in Russian (Корусенко, С. Н. Западносибирские татары: к проблеме этнической и региональной идентичности. Этнокультурные взаимодействия в Евразии: пространственные и исторические конфигурации (с. 91-109). Барнаул: Алтайский государственный педагогический университет).

Lantzeff, G. V., and Pierce, R. 1973. Eastward to Empire. Exploration and Conquest on the Russian Open Frontier, to 1750. Montreal - London: MC. Gill Queen's Press.

Lempert, D. 2014. Classifying Cultures and Identifying Cultural Identities by Relations in Groups: Drawing from Models in Psychology and Ecology. Social Evolution and History 13 (1): 99-134.

Lukina, N. V. 1990. Myths, Legends, Fairy Tales of the Khants and the Mansi. Moscow: Science. In Russian (Лукина, Н. В. Мифы, предания, сказки хантов и манси. М.: Наука). 
Mizgulin, D., and Vychugzhanin, A. 2009. History of Banking of Yugra. Tyumen: Word. Original in Russian (Мизгулин, Д., Вычугжанин, А. История банковского дела Югры. Тюмень: Слово).

Mikhaylovsky, V. M. 2005. Shamanism: Comparative and Ethnographic Sketches. Tyumen: Mandrica. Original in Russian (Михайловский, В. М. Шаманство: сравнительно-этнографические очерки. Тюмень: Мандрика).

Moldanova, T. A. 2016. Symbolical Function of Metal in Culture of Khanty. Original in Russian (Молданова, Т. А. Символическая функиия металла 8 культуре хантов. URL: http://pandia.ru/text/80/075/11280.php).

Naumenko, O. N., Naumenko, E. A., and Bortnikova, Yu. A. 2016. Multiculturalism of Tatar-Christians in Western Siberia as a Result of Confessional Policy in the Russian Empire. Bylye Gody 41 (3): 594-599.

Nikitin, N. I., and Petrov, Yu. A. 2012. Russian Colonization of Siberia and America: Debatable Problems. Vestnik Rossiiskoy natsii 4-5: 35-49. Original in Russian (Никитин, Н. И., Петров, Ю. А. Русская колонизация Сибири и Америки: дискуссионные проблемы. Вестник Российской нации 4-5: 35-49).

Nossilov, K. D. 1904. Among the Voguls. St. Petersburg. Original in Russian (Носилов, К. Д. У вогулов. СПб.).

Pesterev, V. V. 2005. The Organization of the Population in the Colonized Space: Essays on the History of the Colonization of the Trans-Urals of the Late $16^{\text {th }}-$ Early $18^{\text {th }}$ Century. Kurgan: Kurgan State University. Original in Russian (Пестерев, В. В. Организация населения в колонизируемом пространстве: Очерки истории колонизачии Зауралья конца XVI - начала XVIII в. Курган: Курганский государственный университет).

Prokhorchik, M. Yu, and Chikalova, I. R. 2016. Cross-Cultural Interaction of Indigenous People of North America and the European Colonists in the Religious Sphere. Aprobatsiya 5 (44): 113-115. Original in Russian (Прохорчик, М. Ю., Чикалова И. Р. Межкультурное взаимодействие коренного населения Северной Америки и европейских колонистов в религиозной сфере. Апробаиия 5 (44): 113-115).

Pro Town. N.d. History of Siberia. ProTown.ru. URL: http://www.protown.ru/ information/hide/6571.html. Original in Russian (История Сибири. ProTown.ru).

Radlov, V. V. 1885. Das Schamanemtum und seine Kultus. Leipzig.

Seleznyov, A. G., and Seleznyova, I. A. 2004. Siberian Islam: Regional Option of Religious Syncretism. Novosibirsk: SO RAN. Original in Russian (Селезнев, А. Г., Селезнева, И. А. Сибирский ислам: региональный вариант религиозного синкретизма. Новосибирск: СО РАН).

Slezkine, Yu. 1994. Arctic Mirrors: Russia and the Small Peoples of the North. Ithaca and London: Cornell University Press.

Sokolova, Z. P. 2000. Indigenous Peoples of the North. Entsiklopediya Khantymansiiskogo avtonomnogo okruga. Vol. 2 (pp. 169-170). Khanty-Mansiysk: Socrat. In Russian (Соколова, 3. П. Малочисленные народы Севера. Энциклопедия Ханты-Мансийского автономного округа. Т. 2 (с. 169-170). Ханты-Мансийск: Сократ).

Sokolova, Z. P. 2012. Some Debatable Problems of Ob-Ugrian Ethnography. Ural'skij istoricheskij vestnik 4 (37): 92-97. Original in Russian (Соколо- 
ва 3. П. Некоторые дискуссионные вопросы обско-угорской этнографии. Уральский исторический вестник 4 (37): 92-97).

Stingle, M. 1978. Indians without Tomahawks. Moscow: Progress. Original in Russian (Стингл, М. Индейцьы без томагавков. М.: Прогресс).

Sumner, V. N. 1947. Survey of Russian History. New York.

Tsys, V. V. 2015. Barter Trade in North Western Siberia in the Late of $19^{\text {th }}-$ Early $20^{\text {th }}$ Centuries. Bylye Gody 3: 595-601.

Tychinskikh, Z. A. 2011. About Formation of the Siberian-Tatar Identity: To a Question of the Self-Designation and Consciousness. Sulejmanovskie chteniya (pp. 128-133). Tyumen: Express. Original in Russian (Тычинских, 3. А. О формировании сибирско-татарской идентичности: к вопросу о самоназвании и самосознании. Сулеймановские чтения (с. 128-133). Тюмень: Экспресс).

Tylor, E. B. 1989. Primitive Culture. Moscow: Politizdat. Original in Russian (Тейлор Э. Б. Первобытная культура. М.: Политиздат).

Vychugzhanin, A., and Otradnykh, O. 2004. History of Banking of the Tyumen Region. Tyumen: Slovo. Original in Russian (Вычугжанин, А., Отрадных, О. История банковского дела Тюменской области. Тюмень: Слово).

White, D. M. 2006. Indians of North America. Life, Religion, Culture. Moscow: Tsentrpolitpoligraf. Original in Russian (Уайт Д. М. Индейиьы Северной Америки. Быт, религия, культура. М.: Центрполитполиграф).

Yarkov, A. P., and Garifullin, I. B. 2004. Bukharts in Western Siberia. Topos 6: 24-28. Original in Russian (Ярков, А. П., Гарифуллин, И. Б. Бухарцы в Западной Сибири. Топос. Литературно-философский журнал 6: 24-28. URL: http://www.topos.ru/article/2394).

Yarkov, A. P. (ed.) 2007. Islam at the World's End. Islam History in Western Siberia. Vol. 1. Tyumen: Koleso. Original in Russian (Ярков, А. П. Ислам на краю света. История ислама в Западной Сибири. Т. 1. Тюмень: Колесо).

Yarkov, A. P., and Markdorf, N. M. 2010. To a Question of Paradigm Shift of Cultural Development of the Siberian Society. Vestnik Kemerovskogo gosudarstvennogo universiteta 1 (41): 224-227. Original in Russian (Ярков, А. П., Маркдорф, Н. М. К вопросу о смене парадигмы развития культуры сибирского общества. Вестник Кемеровского государственного универсиmema 1 (41): 224-227).

Yeremeyeva, O. I. 2004. Light and Shadows. Essays of History of Spiritual Culture of the People of Northwest Siberia at the Beginning of the $20^{\text {th }}$ Century. Tyumen: Vector Book. Original in Russian (Еремеева, О. И. Свет и тени. Очерки истории духовной культуры народов Северо-Западной Сибири в начале XX века. Тюмень: Вектор-Бук).

Zapadnov, N. L. 2005. Legend about the Yugra Lands. Tyumen: Tyumen. Original in Russian (Западнов, Н. Л. Сказание о земле Югорской. Тюмень: Тюмень).

Archives:

RSAAD - Russian State Archive of Ancient Documents. Original in Russian

(РГАДА - Российский Государственный Архив Древних Актов) 